\title{
Exploring the functional role of the CHRM2 gene in human cognition: results from a dense genotyping and brain expression study
}

\author{
Florencia M Gosso*1,2,3, Eco JC de Geus 1,3, Tinca JC Polderman ${ }^{1}$, \\ Dorret I Boomsma ${ }^{1,2,3}$, Danielle Posthuma ${ }^{1,3}$ and Peter Heutink ${ }^{1,2,3}$
}

\begin{abstract}
Address: ${ }^{1}$ Dept of Biological Psychology, Vrije Universiteit, Amsterdam, The Netherlands, ${ }^{2}$ Section of Medical Genomics, Department of Clinica Genetics, VU Medical Center, Amsterdam, The Netherlands and ${ }^{3}$ Center for Neurogenomics and Cognitive Research - CNCR, Vrije Universiteit, Amsterdam, The Netherlands

Email: Florencia M Gosso* - mf.gosso@vumc.nl; Eco JC de Geus - JCN.de.Geus@psy.vu.nl; Tinca JC Polderman - JC.Polderman@psy.vu.nl; Dorret I Boomsma - DI.Boomsma@psy.vu.nl; Danielle Posthuma - D.Posthuma@psy.vu.nl; Peter Heutink - p.heutink@vumc.nl

* Corresponding author
\end{abstract}

Published: 8 November 2007

BMC Medical Genetics 2007, 8:66 doi:10.1 186/147/-2350-8-66
Received: 23 July 2007

Accepted: 8 November 2007

This article is available from: http://www.biomedcentral.com/I47I-2350/8/66

(C) 2007 Gosso et al; licensee BioMed Central Ltd.

This is an Open Access article distributed under the terms of the Creative Commons Attribution License (http://creativecommons.org/licenses/by/2.0), which permits unrestricted use, distribution, and reproduction in any medium, provided the original work is properly cited.

\begin{abstract}
Background: The CHRM2 gene, located on the long arm of chromosome 7 (7q3I-35), is involved in neuronal excitability, synaptic plasticity and feedback regulation of acetylcholine release, and has been implicated in higher cognitive processing. The aim of this study is the identification of functional (non)coding variants underlying cognitive phenotypic variation.

Methods: We previously reported an association between polymorphisms in the 5'UTR regions of the CHRM2 gene and intelligence.. However, no functional variants within this area have currently been identified. In order to identify the relevant functional variant(s), we conducted a denser coverage of SNPs, using two independent Dutch cohorts, consisting of a children's sample $(\mathrm{N}=37$ I ss; mean age 12.4) and an adult sample $(\mathrm{N}=39 \mathrm{Is}$; mean age 37.6). For all individuals standardized intelligence measures were available. Subsequently, we investigated genotype-dependent CHRM2 gene expression levels in the brain, to explore putative enhancer/inhibition activity exerted by variants within the muscarinic acetylcholinergic receptor.

Results: Using a test of within-family association two of the previously reported variants - rs206 I 174, and rs324650 - were again strongly associated with intelligence $(P<0.0 \mathrm{I})$. A new SNP ( $r$ 2350780) showed a trend towards significance. SNP rs324650, is located within a short interspersed repeat (SINE). Although the function of short interspersed repeats remains contentious, recent research revealed potential functionality of SINE repeats in a gene-regulatory context. Gene-expression levels in postmortem brain material, however were not dependent on rs324650 genotype.

Conclusion: Using a denser coverage of SNPs in the CHRM2 gene, we confirmed the 5'UTR regions to be most interesting in the context of intelligence, and ruled out other regions of this gene. Although no correlation between genomic variants and gene expression was found, it would be interesting to examine allele-specific effects on CHRM2 transcripts expression in much more detail, for example in relation to transcripts specific halve-life and their relation to LTP and memory.
\end{abstract}




\section{Background}

Identifying genes for variation in the range of normal intelligence could provide important clues to the genetic etiology of disturbed cognition in e.g. autism, reading disorder, and ADHD. Since the earliest 90's several groups have focussed on the identification - and subsequent replication - of common genetic polymorphisms underlying normal variation in cognitive abilities [1-5]. Among a handful of candidate genes that have been investigated in relation to normal cognitive variation as summarized in Posthuma \& De Geus 2006 [6], the muscarinic 2 cholinergic receptor gene (CHRM2) has been consistently found to be associated with cognitive ability, and currently is the best replicated gene associated with general intelligence. A population-based association study conducted by Comings et al. (2003) [7] reported an association between a 3'UTR variant of the cholinergic muscarinic receptor 2 (CHRM2) gene explaining 1\% of the variance in scores on full-scale IQ (FSIQ), and years of education. Suggestive evidence for linkage with performance IQ was found at 7q31-36, in the vicinity of the CHRM2 gene in a genome scan for intelligence based on 329 Australian families and 100 Dutch families, totalling 625 sib-pairs [4]. We subsequently reported association between genetic variants within the CHRM2 gene and intelligence quotient (IQ) using two independent Dutch cohorts [8]. This finding was then replicated by Dick and colleagues [9]. All three association studies (Comings et al., 2003; Gosso et al., 2006; Dick et al., 2007) report significant association with IQ and non coding regions within in the CHRM2 gene (rs81919992 located in the 3' untranslated region (UTR) [7], and rs2061174 [9], and rs324650 [8] in introns 4 and 5 , respectively).

The CHRM2 gene belongs to the superfamily of G-protein-coupled receptors (GPCRs). Muscarinic acetylcholine receptors $\left(\mathrm{M}_{1}-\mathrm{M}_{5}\right)$ activate a multitude of signaling pathways important for modulating neuronal excitability, synaptic plasticity and feedback regulation of acetylcholine (ACh) release $[10,11]$. Combined behavioral and pharmacological animal studies involving $\mathrm{M}_{2}$ antagonists have shown the importance of cholinergic receptor activity for acquisition and retrieval of several learning tasks [12-16].

Despite its confirmed putative role in cognitive processes, further evidence for genetic regulatory variants on the CHRM2 gene have been difficult to assess, mainly due to its complex transcriptional expression patterns. Three different CHRM2 promoters have been reported based on work performed on different human cell lines [17]. In combination with alternative splicing patterns this results in, at least, 6 different mRNA transcripts encoding for the same receptor protein (isoforms A till F) $[17,18]$. Promoter activity for the CHRM2 gene was postulated to be tissue specific. The first promoter located upstream of exon 1 , was preferentially used in cardiac cells (isoforms A and B); promoter 2 on intron 1 alternatively expressed on brain (isoforms $\mathrm{C}$ and $\mathrm{D}$ ); and a third promoter located on intro 2 non-tissue specific (isoforms $\mathrm{E}$ and $\mathrm{F}$ ). Independently, Zhou and coworkers [19] reported a fourth putative promoter region on intron 5, but this last result has not been independently confirmed yet [17]. Although CHRM2 promoter usage is believed to be tissue specific, a single protein receptor is encoded. The functional significance of these transcripts is still unknown.

To fine-map the CHRM2 gene and to detect its functional role in cognitive ability, we genotyped a dense set of tagSNPs within and flanking the CHRM2 gene in a sample of 762 Dutch individuals from 358 twin families belonging to two different age cohorts (mean ages 12.4 and 37.6). A family based genetic association test was used, which allows evaluating evidence for association free from spurious effects of population stratification [20-22]. In addition, gene expression assays were performed on brain controls to determine whether a significant correlation exists between the associated SNPs and CHRM2 gene expression levels.

\section{Methods \\ Subjects}

All young and adult twins and their siblings were part of two larger cognitive studies and were recruited from the Netherlands Twin Registry [23,24]. We have shown previously that the adult participants are representative of the Dutch population with respect to intelligence [25]. Informed consent was obtained from the participants (adult cohort) or from their parents if they were under 18 (young cohort). The study was approved by the institutional review board of the VU University Medical Center. None of the individuals tested suffered from severe physical or mental handicaps, as assessed through surveys sent out to participants or their parents every two years.

\section{Young Cohort}

The young cohort consisted of 177 twin pairs born between 1990 and 1992, and 55 siblings [6,26], of which 371 were available for genotyping. Mean age of the genotyped twins was $12.4(\mathrm{SD}=0.9)$ years of age and the siblings were between 8 and 15 years old at the time of testing. There were 35 monozygotic male twin pairs (MZM), 28 dizygotic male twin pairs (DZM), 48 monozygotic female twin pairs (MZF), 23 dizygotic female twin pairs (DZF), 26 dizygotic opposite-sex twin pairs (DOS), 24 male siblings and 24 female siblings, and 3 subjects form incomplete twin pairs ( 1 male, 2 females). Participation in this study included a voluntary agreement to provide buccal swabs for DNA extraction. 
This sample is similar to the sample used in our initial analyses, except for twenty individuals that were deleted from analyses in the current sample due to additional genotyping and a more stringent threshold of genotyping failure per individual.

\section{Adult Cohort}

A total of 793 family members from 317 extended twin families participated in the adult cognition study [4]. Participation in this study did not automatically include DNA collection, however, part of the sample (276 subjects) returned to the lab to provide blood samples. The sample characteristics have been described elsewhere [27]. One hundred fifteen additional individuals provided buccal swabs via our biobanking project [28] for DNA extraction. Mean age of the total genotyped sample was 36.2 years $(S D=12.6)$. There were 25 monozygotic male twin pairs (MZM), 15 dizygotic male twin pairs (DZM), 1 DZM triplet, 20 monozygotic female twin pairs (MZF), 28 dizygotic female twin pairs (DZF) and 23 dizygotic opposite-sex twin pairs (DOS), 29 female siblings and 28 male siblings, and 109 subjects from incomplete twin pairs (41 males, 68 females).

\section{Cognitive testing}

In the young cohort, cognitive ability was assessed with the Dutch adaptation of the WISC-R [29], and consisted of four verbal subtests (similarities, vocabulary, arithmetic, and digit span) and two performance subtests (block design, and object assembly).

In the adult cohort, the Dutch adaptation of the WAISIII$\mathrm{R}$ [30], assessed IQ and consisted of four verbal subtests (VIQ: information, similarities, vocabulary, and arithmetic) and four performance subtests (PIQ: picture completion, block design, matrix reasoning, and digit-symbol substitution). The correlation between verbal IQ and performance IQ is usually around 0.50 (0.53 in our data), implying that only $25 \%$ of the variance in PIQ and VIQ is shared. Thus, a substantial part of the variance in these two measures is non-overlapping, and theoretically they are expected to capture different aspects of cognitive abil- ity. We therefore included VIQ and PIQ as measures of the two different aspects of intelligence as well as Full scale IQ (FSIQ) as a general measure of intelligence. In both cohorts, VIQ, PIQ and FSIQ were normally distributed, (see Table 1).

For both cohorts IQ scores standardized for the effects of age and sex were calculated. These were then z-transformed within cohorts to allow easy comparison across cohorts and across different tests.

\section{DNA collection and isolation}

Buccal swabs were collected from 371 children; DNA in adults was collected from blood samples in 391 adults. The DNA isolation from buccal swabs was performed using a cloroform/isopropanol extraction [31,32]. DNA was extracted from blood samples using the salting out protocol described elsewhere [33]. Zygosity was assessed using 11 highly polymorphic microsatellite markers (Heterozygosity $>0.80$ ). Genotyping was performed blind to familial status and phenotypic data.

\section{DNA and RNA extraction from tissue homogenates}

Control brains from 50 individuals, 23 males with a mean age of 70.3 years $(S D=9.38)$, and 27 females with a mean age of 73.3 years $(S D=10.50)$ were obtained at autopsy from The Netherlands Brain Bank (NBB) [34]. This material comes mainly from the superior and inferior parietal lobe. DNA isolation from 0.20 gram of frozen tissue was performed using the Puregene ${ }^{\mathrm{TM}}$ Kit (Gentra Systems, USA) according to standard protocol and doubled volume of all reagents per tissue weight. To verify DNA isolation, products were run on a $1 \%$ agarose gel.

Total RNA was isolated from 0.10 gram of frozen brain tissue with RNA-Bee ${ }^{\mathrm{TM}}$ following the manufacturer's recommendations (Isotex Diagnostics, Inc., USA). RNA was purified using the Qiagen RNeasy Mini kit (Qiagen Benelux B.V., The Netherlands) and verified on a $2 \%$ agarose gel. Five $\mu \mathrm{g}$ RNA was used to make cDNA using $200 \mathrm{U}$ of Superscript $^{\mathrm{TM}}$ III Reverse Transcriptase (Invitrogen, The Netherlands) in First Strand Buffer (Invitrogen, The Neth-

Table I: Means and standard deviations of IQ (corrected for age and sex effects) in the Young and Adult cohorts

\begin{tabular}{|c|c|c|c|c|c|c|c|c|}
\hline & Young Cohort & & & & Adult Cohort & & & \\
\hline & Total sample & $\begin{array}{c}\text { Skewness } \\
\text { Kurtosis }\end{array}$ & Genotyped & $\begin{array}{c}\text { Skewness } \\
\text { Kurtosis }\end{array}$ & Total sample & $\begin{array}{c}\text { Skewness } \\
\text { Kurtosis }\end{array}$ & Genotyped & $\begin{array}{l}\text { Skewness } \\
\text { Kurtosis }\end{array}$ \\
\hline $\mathrm{N}$ & 407 & & 371 & & 793 & & 391 & \\
\hline Gender (M/F) & $191 / 216$ & & $176 / 195$ & & $348 / 445$ & & $175 / 216$ & \\
\hline Age (SD) & $12.37(0.93)$ & & $12.37(0.92)$ & & $37.60(13.00)$ & & $36.25(12.64)$ & \\
\hline PIQ (SD) & 94.57 (18.93) & $0.165 /-0.308$ & $94.85(19.14)$ & $0.175 /-0.304$ & $104.49(12.34)$ & $0.197 / 0.099$ & $104.30(11.64)$ & $0.135 / 0.312$ \\
\hline VIQ(SD) & $102.56(12.74)$ & $0.121 / 0.242$ & $102.64(12.92)$ & $-0.080 /-0.332$ & $103.69(12.26)$ & $-0.308 /-0.005$ & $104.23(12.15)$ & $-0.410 / 0.256$ \\
\hline FSIQ (SD) & $98.65(15.06)$ & $-0.042 /-0.252$ & $98.84(15.24)$ & $-0.037 /-0.254$ & $103.56(11.49)$ & $0.087 / 0.167$ & $103.81(11.16)$ & $0.073 / 0.512$ \\
\hline
\end{tabular}


erlands), $3.4 * 10^{-2} \mu \mathrm{g} / \mu \mathrm{l}$ random hexamer oligo, $3.4 * 10^{-}$ ${ }^{2} \mu \mathrm{g} / \mu \mathrm{l}$ poly d(T) $12-18,1.3 \mathrm{mM}$ dNTPs, $1.1 \mu \mathrm{M}$ DTT (Invitrogen, The Netherlands), 10 U RNaseOUT ${ }^{\mathrm{TM}}$ Ribonuclease Inhibitor Recombinant (Invitrogen, The Netherlands) and incubated two hours at $50^{\circ} \mathrm{C}$. Subsequently, $20 \mathrm{U}$ RNase $\mathrm{H}$ (Invitrogen, The Netherlands) was added and incubated 30 minutes at $37^{\circ} \mathrm{C}$. Products were run on a $1 \%$ agarose gel to examine the quality.

\section{Genotyping}

Single nucleotide polymorphisms (SNPs) were selected using the information available from the International HapMap Project. SNP selection was based on a randomly selected population with northern and western European ancestry by the Centre d'Etude du polymorphisme Humain (CEPH) [35]. The Minor Allele Frequency MAF had to be $>0.05$ in order to exclude rare homozygous genotypes. Forty-two SNPs within the CHRM2 gene were thus selected from the CEPH population using Haploview version 3.32 (NCBI build 36.1).

SNP genotyping was performed using the SNPlex ${ }^{\circledast}$ assay platform. The SNPlex assay was conducted following the manufacturer's recommendations (Applied Biosystems, Foster city, CA, USA). All pre-PCR steps were performed on a cooled block. Reactions were carried out in Gene Amp 9700 Thermocycler (Applied Biosystems, Foster city, CA, USA). Data was analyzed using Genemapper v3.7 (Applied Biosystems, Foster city, CA, USA).

\section{CHRM2 transcripts at brain level}

Three different primer combinations were used to investigate the presence of CHRM2 transcript variants in normal brain controls. Forward primers $\mathrm{F}_{\mathrm{A} \& \mathrm{~B}} \mathrm{GAGGCATCCAG-}$

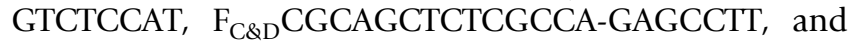
$\mathrm{F}_{\mathrm{E} \& \mathrm{~F}} \mathrm{AAAGGACTCCTCGCTCCTTC}$ were used in combination with a unique reverse primer $\mathrm{R}_{\mathrm{A}-\mathrm{F}} \mathrm{CCCGATAATGGT-}$ CACCAAAC in order to tag isoforms A till F. PCR was performed at $94^{\circ} \mathrm{C}$ for $30 \mathrm{sec}, 55^{\circ} \mathrm{C}$ for $30 \mathrm{sec}$, and $72^{\circ} \mathrm{C}$ for $1: 30 \mathrm{~min}$, for 40 cycles, followed by a $7 \mathrm{~min}$ extension at $72{ }^{\circ} \mathrm{C}$. To verify primers specificity PCR products were run on a $2 \%$ agarose gel.

\section{Gene expression assay}

RT-PCR was performed using specific primers encompassing the untranslated exon 5 (the last untranslated exon), which is present in all mRNA transcripts, and the coding sequence (CDS) of the CHRM2 gene; F-GAAACCAGCGACAGGTTTAAATG, R-GCTATTGTTAGAGGAGTTTGTTGAGTTATTC. PCR was carried out at $94^{\circ} \mathrm{C}$ for 1 $\min , 64^{\circ} \mathrm{C}$ for $1 \mathrm{~min}$, and $72^{\circ} \mathrm{C}$ for $1 \mathrm{~min}$, for 40 cycles, followed by a $10 \mathrm{~min}$ extension at $72^{\circ} \mathrm{C}$. Optimization of primer concentration and cDNA input was performed and dissociation curves for the selected primers obtained. Two housekeeping genes - $\beta$-actin and HPRT - were used as internal controls. RT-PCR reactions were performed twice independently, each time in duplicate.

\section{Statistical analyses}

Allele frequencies of all SNPs were estimated in both the children and adult cohorts using Haploview [36] in which a Hardy-Weinberg test is implemented, based on an exact calculation of the probability of observing a certain number of heterozygotes conditional on the number of copies of the minor SNP allele.

Genetic association tests were conducted using the program QTDT which implements the orthogonal model proposed by Abecasis et al., 2000 [20] (see also Fulker et al., 1999; Posthuma et al., 2004 [21,22]). This model allows one to decompose the genotypic effect into orthogonal between- $\left(\beta_{\mathrm{b}}\right)$ and within- $\left(\beta_{\mathrm{w}}\right)$ family components, and also models the residual sib-correlation as a function of polygenic or environmental factors. $\mathrm{MZ}$ twins can be included and are modelled as such, by adding zygosity status to the datafile. They are not informative to the within family component (unless they are paired with non-twin siblings), but are informative for the between family component. The between-family association component is sensitive to population admixture, whereas the within-family component is significant only in the presence of LD due to close linkage. The models used in QTDT take into account additive allelic between- and within family effects.

It is worth noting that, if population stratification acts to create a false association, the test for association using the within family component is still valid. More importantly, if population stratification acts to hide a genuine association, the test for association using the within family component has more power to detect this association than a population based association test. A significance level $\alpha$ of 0.01 was chosen.

\section{Results}

Genotyping success rate was 95.36 (SD = 3.80) among both cohorts. Six tag-SNPs, (rs6957496, rs1424569, rs10488600, rs17494540, rs324582, and rs11773032), although with high genotyping rate, deviated from HWE $(P<0.05)$ despite a high genotype call rate. One tag-SNP, rs11773032 showed no variation in our population and was thus deleted from further analysis. LD parameters D' and $\mathrm{r}^{2}$ were obtained for all successfully genotyped SNPs. LD blocks were generated applying the algorithm defined by Gabriel et al., 2002 [37] in which confidence bounds on $D^{\prime}$ are generated if $95 \%$ of the information shows "strong LD". By default, this method ignores markers with MAF < 0.05 (see Figure 1 and Table 2). 


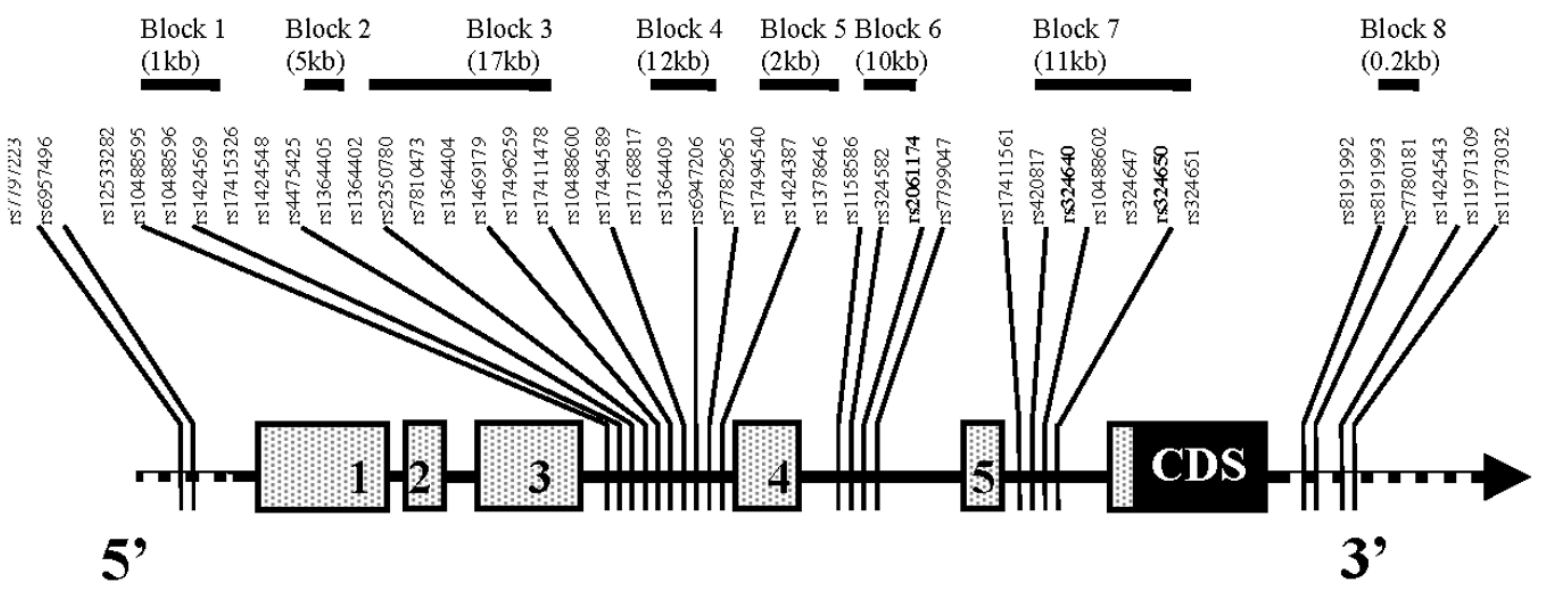

\section{Figure I}

Location of single nucleotide polymorphisms (SNPs) within the CHRM2 gene on chromosome 7 and LD blocks defined by them, respectively. Coding sequence (CDS) is depicted in black. Untranslated exons (Exon I till Exon 5) are depicted in grey. SNPs already reported in our previous study (Gosso et al., 2006) are in bold.

Two 5'UTR SNPs, previously reported, showed the strongest association with IQ, rs2061174 (intron 4) in the adult cohort and rs324650 (intron 5) in the young cohort [8] (see Figure 2). Within-family genetic effects were reflected in an increased IQ of 6.89 (PIQ) points for those individuals carrying the "A" allele of rs2061174 within the adult cohort. individuals in the young cohort bearing the "T" allele of rs324650 showed an increment of 5.30 IQ (VIQ) points (see Tables 3, 4 and 5). Interestingly, the most significant variant in the young cohort, rs324650, is part of a short interspersed repeat (SINE), namely a MIRb (mammalian-wide interspersed repeat) repeat of $160 \mathrm{bp}$ long. The derived " $\mathrm{T}$ " allele contained in this repeat seems to be human-specific. In addition this MIRb repeat is also present in non-human primate linages - rhesus (macaca mulatta) and chimpanzee (pan troglodytes) - but not in other mammalian linages. Such an allele-specific effect may reflect that the variant is in LD with the causal allele, or that the "T" allele is directly modifying binding-properties of transcription starting sites (TSS) [38].

\section{CHRM2 transcripts expression at brain level and correlations with CHRM2 tag-SNPs}

Previous studies have shown that of the six known isoforms of CHRM2 only $\mathrm{C}$ and $\mathrm{D}$ are expressed in the brain $[17,18]$. In contrast to this, we observed all six CHRM2 transcripts isoforms in brain material(data not shown).

After normalizing raw gene expression data to expression level of the housekeeping genes, no correlation between gene expression and CHRM2 gene genotypes for SNPs rs2061174, rs324640 or rs324650 was observed (data not shown).

\section{Discussion}

Converging evidence from previous studies [7-9] has pointed to a role of the CHRM2 gene in intelligence. None of these studies, however, have identified the functional polymorphism explaining its role at a molecular level. The present study aimed to zoom in on the functional variants, by fine-mapping the most significant areas within this gene and also investigating differential brain expression as a function of different genotypes on the SNPs most strongly related to intelligence.

A total of 42 SNPs within the CHRM2 gene were genotyped in a young and adult cohort. Association analysis was conducted separately in both age cohorts to detect possible age dependent gene effects. Associations were found in different regions of the gene for each age cohort. Our current analyses showed that the same SNPs that were associated previously with intelligence, were again most significant, whereas a new SNP (rs2350780) showed a trend towards significance. Because of the dense coverage of SNPs used in this study, this confirms the importance of intron 4 and intron 5 regions, but rules out association with SNPs located elsewhere in the gene.

Four new SNPs in the intron 3 region, (rs2350780, rs1364409, rs7782965, and 1378646) showed association with PIQ in the adult cohort. These SNPs are in high LD ( $\mathrm{r}^{2}$ between $0.58-0.72$ ) between the most significant SNPs. SNP rs2350780 and rs2061174 were also found to 
Table 2: SNPs descriptives for young, adult and combined cohorts

\begin{tabular}{|c|c|c|c|c|c|c|c|c|c|c|}
\hline & & rs\# & Position $^{\mathrm{a}}$ & Tagged SNP & LD $_{\text {BLOCK }}$ & MA & MAF Young & MAF Adult & HWE-pval & $\%$ Geno \\
\hline 1 & $5^{\prime} U T R$ & rs7797223 & 136198443 & & & $\mathrm{~T}$ & 0.25 & 0.26 & 0.77 & 95.6 \\
\hline 2 & & rs6957496 & I 36202377 & 1 & & G & 0.09 & 0.11 & 0.02 & 96.6 \\
\hline 3 & intron 3 & rsI 2533282 & 136207518 & I, 4, 5, & $\mathrm{I}(\mathrm{I}$ kb) & G & 0.18 & 0.17 & 0.40 & 98.6 \\
\hline 4 & & rs 10488595 & 136208970 & & & A & 0.18 & 0.17 & 0.71 & 97.7 \\
\hline 5 & & rsl0488596 & 136209134 & & & $\mathrm{~T}$ & 0.18 & 0.16 & 0.37 & 97.2 \\
\hline 6 & & rs I424569 & 136211219 & & & A & 0.44 & 0.47 & 0.02 & 94.8 \\
\hline 7 & & rs174I5326 & $|362| 4872$ & & & C & 0.02 & 0.05 & 0.48 & 95.1 \\
\hline 8 & & rs|424548 & 136219956 & & & $\mathrm{~T}$ & 0.37 & 0.36 & 0.53 & 98.2 \\
\hline 9 & & rs4475425 & 136225739 & & $2(5 \mathrm{~Kb})$ & A & 0.21 & 0.24 & 0.87 & 94.8 \\
\hline 10 & & rsI364405 & 136231025 & 41 & & A & 0.35 & 0.33 & 0.08 & 97.9 \\
\hline II & & rsI364402 & 136234903 & & 3 (17 kb) & C & 0.12 & 0.11 & 1.00 & 98.7 \\
\hline 12 & & rs2350780 & 136243509 & & & G & 0.40 & 0.39 & 0.59 & 98.8 \\
\hline 13 & & rs7810473 & 136246997 & & & G & 0.42 & 0.42 & 0.30 & 98.9 \\
\hline 14 & & rs 1364404 & I36248827 & & & $\mathrm{T}$ & 0.31 & 0.32 & 0.62 & 98.1 \\
\hline 15 & & rs1469179 & $|3625| 497$ & 22 & & A & 0.44 & 0.46 & 0.18 & 97.3 \\
\hline 16 & & rs 17496259 & $|3625| 883$ & & & $A$ & 0.31 & 0.31 & 0.48 & 95.8 \\
\hline 17 & & rs $1741 \mid 478$ & 136251909 & & & $\mathrm{~T}$ & 0.31 & 0.32 & 0.37 & 99.1 \\
\hline 18 & & rs 10488600 & 136255998 & & & $\mathrm{~T}$ & 0.10 & 0.13 & 0.00 & 98.0 \\
\hline 19 & & rsI7494589 & 136256129 & 26 & & A & 0.20 & 0.18 & 0.07 & 94.9 \\
\hline 20 & & rs|7|688|7 & 136258808 & & & $\mathrm{~T}$ & 0.08 & 0.06 & 0.87 & 99.2 \\
\hline 21 & & rs|364409 & 136262573 & & $4(12 \mathrm{~kb})$ & $\mathrm{T}$ & 0.32 & 0.35 & 0.13 & 96.4 \\
\hline 22 & & rs6947206 & $|3626565|$ & & & C & 0.46 & 0.48 & 0.12 & 94.0 \\
\hline 23 & & rs7782965 & 136274673 & $21,26,27$ & & $\mathrm{~T}$ & 0.32 & 0.35 & 0.45 & 90.4 \\
\hline 24 & & rsI7494540 & 136277380 & & & C & 0.20 & 0.18 & 0.01 & 96.3 \\
\hline 25 & & rsI424387 & 136282543 & & & C & 0.31 & 0.31 & 0.39 & 99.0 \\
\hline 26 & & rs 1378646 & |3628554| & & $5(2 \mathrm{~kb})$ & G & 0.35 & 0.37 & 0.32 & 98.8 \\
\hline 27 & intron 4 & rsII58586 & 136287676 & & & G & 0.34 & 0.40 & 0.42 & 93.0 \\
\hline 28 & & rs324582 & $|3630| \mid 47$ & & & G & 0.07 & 0.10 & 0.02 & 96.4 \\
\hline 29 & & rs206III4 & 136311940 & 30 & $6(10 \mathrm{~kb})$ & G & 0.34 & 0.35 & 0.93 & 84.6 \\
\hline 30 & & rs7799047 & 136322098 & & & G & 0.34 & 0.35 & 1.00 & 93.5 \\
\hline 31 & intron 5 & rsI74II56I & 136332728 & $14,16,17,25$ & & C & 0.32 & 0.25 & 0.25 & 87.7 \\
\hline 32 & & rs420817 & 136337943 & & $7(\mathrm{ll} \mathrm{kb})$ & C & 0.48 & 0.47 & 0.21 & 95.7 \\
\hline 33 & & rs324640 & 136339536 & 32 & & G & 0.46 & 0.50 & 0.17 & 86.2 \\
\hline 34 & & rs 10488602 & $13634 \mid 043$ & & & C & 0.22 & 0.23 & 0.43 & 98.1 \\
\hline 35 & & rs324647 & I36343292 & & & C & 0.14 & 0.15 & 0.13 & 95.9 \\
\hline 36 & & $r s 324650$ & $|3634420|$ & & & $\mathrm{T}$ & 0.47 & 0.48 & 0.08 & 85.2 \\
\hline 37 & & rs32465I & $|3634980|$ & 35 & & $\mathrm{~T}$ & 0.14 & 0.14 & 0.13 & 93.1 \\
\hline 38 & 3'UTR & rs8191992 & $13635 \mid 848$ & & $8(0.2 \mathrm{~kb})$ & $\mathrm{T}$ & 0.45 & 0.48 & 0.60 & 96.5 \\
\hline 39 & & rs8191993 & 136352103 & & & G & 0.35 & 0.35 & 0.93 & 94.9 \\
\hline 40 & & rs7780I8I & 136357075 & & & G & 0.42 & 0.44 & 0.83 & 98.7 \\
\hline 41 & & rsI424543 & 136360300 & & & C & 0.36 & 0.32 & 0.01 & 95.4 \\
\hline 42 & & rsII97I309 & 136362695 & 8 & & $\mathrm{~T}$ & 0.38 & 0.37 & 0.57 & 90.0 \\
\hline 43 & & rsII 773032 & $13639 \mid 582$ & & & $A$ & 0.00 & 0.01 & 1.00 & 98.1 \\
\hline
\end{tabular}

a Chromosomal single nucleotide position (SNP) position based on Build 36.I. Tag-SNPs are depicted in bold. Abbreviations: LD, Linkage disequilibrium; MA, Minor Allele, MAF Minor Allele Frequency; HWE, Hardy-Weinberg Equilibrium

be associated with intelligence by Dick and co-workers [9]. These intronic SNPs are located $68 \mathrm{~kb}$ apart in introns 3 and 4 , respectively. In our cohort, LD between these two variants is 0.58 .
We found the most significant associations with PIQ in adults (rs2061174, $\left.\chi^{2}=9.14 ; P=0.003\right)$ and with VIQ in children (rs323650, $\chi^{2}=9.50 ; P=0.002$ ). Because only part of the variance in PIQ and VIQ is shared, and these results might reflect brain maturation processes and agerelated genetic effects. Alternatively, the results could 

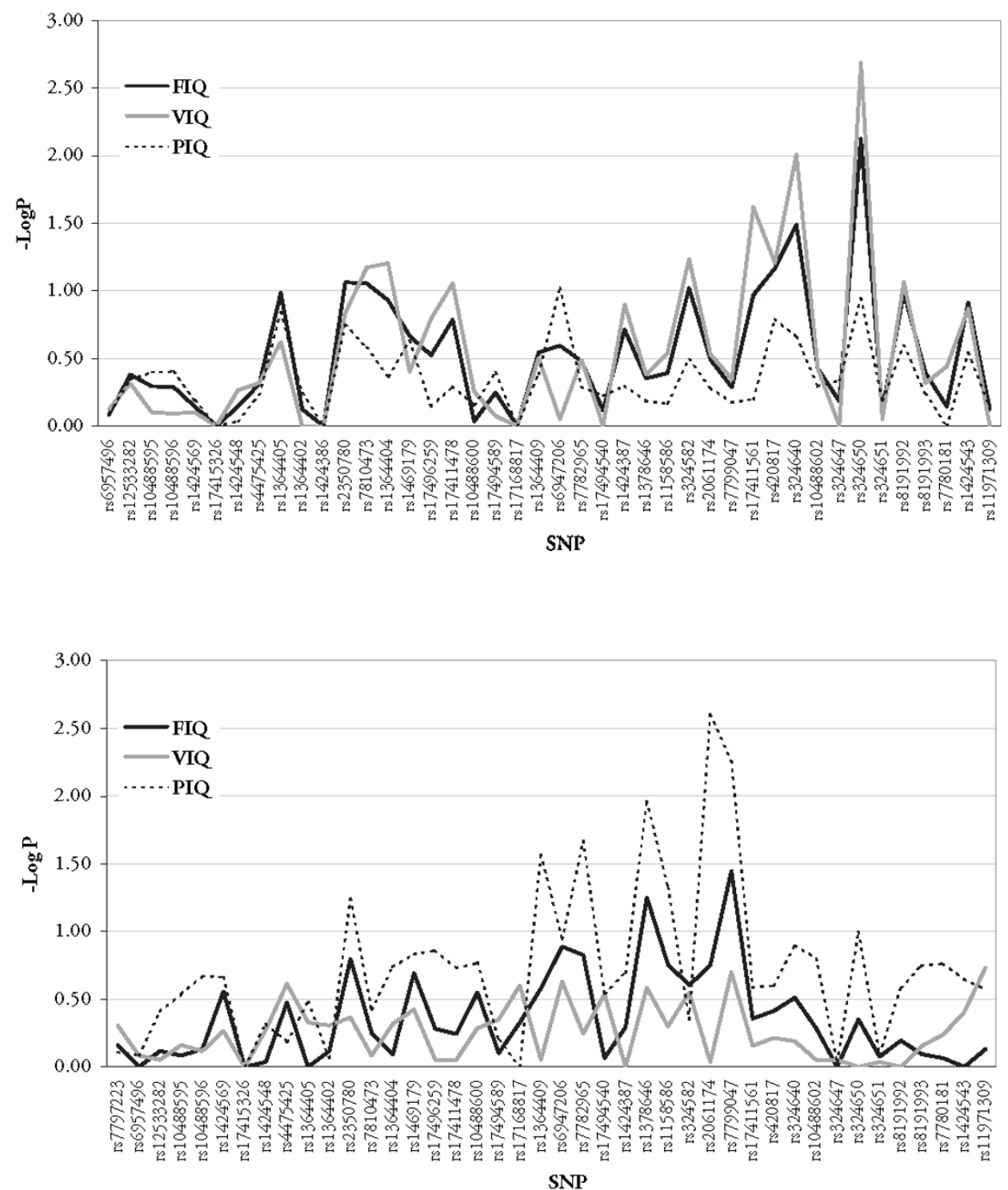

Figure 2

QTDT family-based results for tag-SNPs plotted against FSIQ, VIQ, and PIQ for young (A) and adult (B)cohorts.

point to, and potentially explain, the genetic overlap between PIQ and VIQ, in which common genetic variants do not only interact modulating hippocampal neurotransmitter activity, but also and even more interesting from the epigenetic point of view, they might modulate priming and dendritic outgrowth underlying synaptic plasticity during embryogenesis [39] and at a post-natal stage [40], reflecting phenotypic variation at different IQ domains across the lifespan.

From a developmental perspective, brain maturation can be considered the most complex and dynamic lifelong process taking place in humans. Neuronal plasticity patterns (e.g. dendritic "pruning", synapse elimination, myelination) have been shown to vary significantly across life and among diverse brain structures (for a review see Toga et al., 2006 [41]). Variation in cognitive phenotypes may be the result of diverse allele-dependent effects that, although small in effect size, may contribute to cognitive phenotypes outcomes across life.

In situ hybridization experiments on mammals (e.g. mice) [42] have been of great utility to aid specific localization and interpretation of gene expression patterns. However, 
Table 3: Means (SD) per genotype for PIQ, VIQ and FIQ for young and adult cohorts for the most significant SNPs within the CHRM2 gene

\begin{tabular}{|c|c|c|c|c|c|c|c|c|c|}
\hline \multirow{2}{*}{$\begin{array}{c}\text { SNP } \\
\text { position } \\
\text { (bp) }\end{array}$} & \multirow{2}{*}{ Phenotype } & \multicolumn{3}{|c|}{$\begin{array}{c}\text { Young Cohort } \\
\text { Genotype Frequency }\end{array}$} & \multirow{2}{*}{$\begin{array}{c}\text { Total } \\
\mathbf{N}\end{array}$} & \multicolumn{3}{|c|}{ Adult Cohort } & \multirow{2}{*}{$\begin{array}{c}\text { Tota } \\
\mathbf{N}\end{array}$} \\
\hline & & AA & AG & GG & & AA & AG & GG & \\
\hline & & 0.38 & 0.46 & 0.17 & & 0.39 & 0.47 & 0.14 & \\
\hline rs2350780 & PIQ & $94.43(18.96)$ & $95.21(19.86)$ & 95.94 (I7.59) & 366 & $104.77(12.93)$ & 104.61 (1 I.44) & $104.37(10.81)$ & 359 \\
\hline \multirow[t]{4}{*}{ (I36243509) } & VIQ & $102.24(13.67)$ & $103.07(12.69)$ & 104.17 (11.67) & 367 & $104.81(13.56)$ & $104.19(11.00)$ & $104.40(11.43)$ & 359 \\
\hline & FIQ & 98.38 (I5.54) & 99.11 (15.26) & 100.79 (13.70) & 366 & $104.54(12.82)$ & $103.89(10.50)$ & $103.77(10.18)$ & 359 \\
\hline & & AA & AT & TT & & AA & AT & TT & \\
\hline & & 0.44 & 0.47 & 0.09 & & 0.42 & 0.45 & 0.13 & \\
\hline rs 1364409 & PIQ & $95.30(19.27)$ & 93.93 (18.99) & $97.16(19.92)$ & 361 & $105.16(12.83)$ & $104.52(11.30)$ & $104.31(10.57)$ & 350 \\
\hline \multirow[t]{4}{*}{$(136262573)$} & VIQ & $102.30(13.91)$ & $102.93(12.01)$ & $105.86(12.48)$ & 362 & $104.61(12.56)$ & $104.45(11.76)$ & $104.02(10.85)$ & 350 \\
\hline & FIQ & $98.72(16.00)$ & $98.47(|4.3|)$ & $102.82(15.57)$ & 361 & $104.56(12.20)$ & $104.03(11.03)$ & $103.49(9.34)$ & 350 \\
\hline & & CC & CT & TT & & CC & CT & TT & \\
\hline & & 0.44 & 0.46 & 0.10 & & 0.42 & 0.46 & 0.13 & \\
\hline rs7782965 & PIQ & $95.14(19.46)$ & $93.97(19.25)$ & $96.66(19.06)$ & 345 & $104.35(11.87)$ & I04.8I (1I.5I) & $104.50(10.67)$ & 345 \\
\hline \multirow[t]{4}{*}{ (136274673) } & $\mathrm{VIQ}$ & $101.96(14.03)$ & $102.56(11.75)$ & $105.31(13.17)$ & 346 & $104.04(12.35)$ & $104.47(11.61)$ & $103.66(10.93)$ & 345 \\
\hline & FIQ & $98.43(16.17)$ & $98.28(14.35)$ & $102.18(15.52)$ & 345 & $103.85(11.53)$ & $104.16(11.08)$ & $103.34(9.35)$ & 345 \\
\hline & & AA & AG & GG & & $\mathbf{A A}$ & AG & GG & \\
\hline & & $0.4 I$ & 0.48 & 0.11 & & 0,39 & 0,46 & 0,15 & \\
\hline rsI378646 & PIQ & $95.87(18.83)$ & $93.78(18.93)$ & $96.80(19.62)$ & 365 & $104.52(13.00)$ & $\begin{array}{l}104.92 \\
(11.160\end{array}$ & 104.61 (10.59) & 363 \\
\hline \multirow[t]{4}{*}{$(|362| 4872)$} & VIQ & $102.21(14.06)$ & $103.03(11.85)$ & $104.41(12.74)$ & 366 & $104.06(13.22)$ & $105.03(11.61)$ & $103.87(11.01)$ & 363 \\
\hline & $\mathrm{FIQ}$ & $98.97(15.80)$ & $98.48(14.24)$ & 101.62 (15.39) & 365 & $103.98(12.73)$ & $104.55(10.72)$ & $103.50(9.5 \mathrm{I})$ & 363 \\
\hline & & AA & AG & GG & & AA & AG & GG & \\
\hline & & 0.44 & 0.44 & 0.12 & & 0.42 & 0.47 & 0.11 & \\
\hline rs206II74 & PIQ & $95.56(18.61)$ & $93.58(20.13)$ & $96.66(18.12)$ & 363 & $103.33(12.8 I)$ & $105.34(11.33)$ & $105.11(9.40)$ & 389 \\
\hline \multirow{4}{*}{$(|363| 1940)$} & VIQ & $101.55(13.93)$ & $102.89(12.32)$ & $106.34(11.77)$ & 364 & $103.60(13.62)$ & $105.36(11.03)$ & $102.64(10.43)$ & 389 \\
\hline & $\mathrm{FIQ}$ & $98.40(15.60)$ & $98.40(15.37)^{\prime}$ & $102.14(14.06)$ & 363 & $103.16(12.82)$ & $104.93(10.23)$ & $102.88(8.97)$ & 389 \\
\hline & & TT & CT & CC & & TT & CT & CC & \\
\hline & & 0.48 & 0.42 & 0.10 & & 0.59 & 0.34 & 0.07 & \\
\hline rsl74II56I & PIQ & $87.19(19.37)$ & $95.95(18.21)$ & $94.89(19.64)$ & 345 & $107.15(11.31)$ & $103.48(11.47)$ & $105.02(11.83)$ & 307 \\
\hline \multirow{4}{*}{$(136332728)$} & VIQ & $99.53(12.25)$ & $103.45(12.94)$ & 103.71 (12.72) & 346 & $108.09(10.22)$ & $103.21(10.44)$ & $104.54(12.44)$ & 307 \\
\hline & $\mathrm{FIQ}$ & $92.72(15.08)$ & $99.94(14.63)$ & 99.54 (I5.76) & 345 & $107.24(10.13)$ & $102.78(10.31)$ & $104.39(11.61)$ & 307 \\
\hline & & AA & AG & GG & & AA & AG & GG & \\
\hline & & 0.29 & 0.50 & 0.21 & & 0,25 & 0,49 & 0,26 & \\
\hline rs324640 & PIQ & 94.72 (19.94) & 94.04 (19.09) & 96.61 (18.68) & 363 & $102.21(12.83)$ & $105.64(11.55)$ & 104.37 (II.03) & 386 \\
\hline \multirow[t]{4}{*}{ (136339536) } & VIQ & $101.70(13.90)$ & 102.77 (I2.79) & $103.88(12.38$ & 364 & $102.81(13.92)$ & $105.69(11.70)$ & $103.35(11.26)$ & 386 \\
\hline & FIQ & $97.88(16.29)$ & $98.53(14.79)$ & $100.83(15.15)$ & 363 & $102.08(12.6 I)$ & $105.36(11.12)$ & $103.17(10.02)$ & 386 \\
\hline & & AA & AT & TT & & AA & AT & TT & \\
\hline & & 0.30 & 0.48 & 0.21 & & 0.26 & 0.48 & 0.26 & \\
\hline rs324650 & PIQ & 93.59 (19.42) & 94.45 (19.20) & $96.82(18.40)$ & 363 & $102.59(12.5 \mathrm{I})$ & $105.50(11.83)$ & $104.19(11.11)$ & 369 \\
\hline \multirow[t]{2}{*}{$(136344201)$} & VIQ & $101.43(13.98)$ & $102.73(12.76)$ & $104.36(11.92)$ & 364 & 103.37 (13.52) & 105.61 (11.69) & $102.83(11.48)$ & 369 \\
\hline & $\mathrm{FIQ}$ & 97.14 (15.99) & $98.73(14.95)$ & $101.26(14.60)$ & 363 & $102.54(12.28)$ & $105.25(11.38)$ & $102.83(10.21)$ & 369 \\
\hline
\end{tabular}

the localization of CHRM2 receptors transcripts has been conducted using probe sequences that did not distinguish between alternatively spliced transcripts. Our gene expression analyses showed that, in contrast to previously reported findings $[17,18]$, all six currently known transcripts (isoforms A till F) of the CHRM2 gene were present in brain tissue.

Our genotype-dependent CHRM2 expression, did not reveal functional significance of any of the SNPs that were significantly related to intelligence. However, one should keep in mind that at this point we were only able to study material from superior and inferior parietal lobe and further studies on other brain regions might give different results. Furthermore it would be of interest to examine allele-specific effects on CHRM2 transcripts expression in much more detail, for example in relation to transcripts specific halve-life and their relation to LTP and memory.

Although brain expression analysis did not reveal differential expression of CHRM2 transcripts, our study further zooms in on the CHRM2 gene, clearly confirming two 
Table 4: Population and family-based QTDT results for young cohort for the most significant variants among CHRM2 gene

\begin{tabular}{|c|c|c|c|c|c|c|c|c|c|}
\hline \multirow[b]{2}{*}{ position (bp) } & \multicolumn{3}{|c|}{ Population-based } & \multicolumn{5}{|c|}{ Family-based } & \multirow[b]{2}{*}{ GE } \\
\hline & Phenotype & $\mathbf{N}_{\text {POPULATION }}$ & $\chi^{2}$ & $\mathbf{P}$ & GE & $\mathbf{N}_{\text {FAMILY }}$ & $\chi^{2}$ & $\mathbf{P}$ & \\
\hline rs2350780 & $\mathrm{PIQ}$ & 366 & 0.74 & 0.390 & $\mathrm{I} .34(\mathrm{G})$ & 95 & 1.81 & 0.179 & $3.63(\mathrm{~A})$ \\
\hline \multirow[t]{2}{*}{$(136243509)$} & VIQ & 366 & 1.62 & 0.203 & $\mathrm{I} .42(\mathrm{G})$ & 95 & 2.11 & 0.147 & $2.47(\mathrm{~A})$ \\
\hline & FSIQ & 366 & 1.82 & 0.177 & $1.68(\mathrm{G})$ & 95 & 2.94 & 0.086 & $3.48(\mathrm{~A})$ \\
\hline rsI364409 & PIQ & 362 & 0.13 & 0.718 & $0.57(\mathrm{~T})$ & 96 & 0.67 & 0.413 & $2.33(\mathrm{~A})$ \\
\hline \multirow[t]{2}{*}{$(136262573)$} & VIQ & 362 & 1.46 & 0.227 & $1.42(\mathrm{~T})$ & 96 & 1.02 & 0.313 & $\mathrm{I} .84(\mathrm{~A})$ \\
\hline & FSIQ & 362 & 0.92 & 0.337 & $1.37(\mathrm{~T})$ & 96 & 1.14 & 0.286 & $2.23(\mathrm{~A})$ \\
\hline rs7782965 & PIQ & 346 & 0.17 & 0.680 & $0.77(\mathrm{~T})$ & 85 & 0.18 & 0.671 & $2.00(\mathrm{C})$ \\
\hline \multirow[t]{2}{*}{$(136274673)$} & VIQ & 346 & 1.57 & 0.210 & $\mathrm{I} .42(\mathrm{~T})$ & 85 & 0.43 & 0.512 & $\mathrm{I} .74(\mathrm{C})$ \\
\hline & FSIQ & 346 & 1.03 & 0.310 & $\mathrm{I} .37(\mathrm{~T})$ & 85 & 0.94 & 0.332 & $2.05(\mathrm{C})$ \\
\hline rs 1378646 & PIQ & 366 & 0.00 & 1.000 & $0.00(\mathrm{G})$ & 98 & 0.20 & 0.655 & $1.26(\mathrm{~A})$ \\
\hline \multirow[t]{2}{*}{$(|362| 4872)$} & VIQ & 366 & 0.88 & 0.348 & $\mathrm{I} .03(\mathrm{G})$ & 98 & 0.66 & 0.417 & $1.39(\mathrm{~A})$ \\
\hline & FSIQ & 366 & 0.32 & 0.572 & $0.76(\mathrm{G})$ & 98 & 0.59 & 0.442 & $1.55(\mathrm{~A})$ \\
\hline rs206II 74 & PIQ & 363 & 0.01 & 0.920 & $0.19(\mathrm{G})$ & 111 & 0.41 & 0.522 & $1.69(\mathrm{~A})$ \\
\hline \multirow[t]{2}{*}{$(136311940)$} & VIQ & 363 & 3.25 & 0.071 & $1.94(\mathrm{G})$ & 111 & 1.10 & 0.294 & $1.68(\mathrm{~A})$ \\
\hline & FSIQ & 363 & 1.10 & 0.294 & 1.37 (G) & 111 & 0.98 & 0.322 & $1.91(\mathrm{~A})$ \\
\hline rs $174|I 56|$ & PIQ & 345 & 1.20 & 0.273 & $1.91(\mathrm{C})$ & 85 & 0.23 & 0.632 & 1.47 (C) \\
\hline \multirow[t]{2}{*}{$(136332728)$} & VIQ & 345 & 2.51 & 0.113 & $1.81(\mathrm{C})$ & 85 & 5.09 & 0.024 & $4.35(\mathrm{C})$ \\
\hline & FSIQ & 345 & 2.79 & 0.095 & $2.29(\mathrm{C})$ & 85 & 2.59 & 0.108 & 3.61 (C) \\
\hline rs324640 & PIQ & 363 & 0.62 & 0.620 & $\mathrm{I} .34(\mathrm{G})$ & 105 & 1.51 & 0.219 & $3.45(\mathrm{~A})$ \\
\hline \multirow[t]{2}{*}{$(136339536)$} & VIQ & 363 & $2.83^{*}$ & 0.093 & $1.94(G)$ & 105 & 6.67 & 0.010 & 4.59 (A) \\
\hline & FSIQ & 363 & 2.39 & 0.122 & $1.98(\mathrm{G})$ & 105 & 4.57 & 0.033 & $4.42(\mathrm{~A})$ \\
\hline rs324650 & PIQ & 363 & 1.65 & 0.199 & $2.10(\mathrm{~T})$ & 100 & 2.51 & 0.113 & $4.40(\mathrm{~T})$ \\
\hline \multirow[t]{2}{*}{$(|3634420|)$} & VIQ & 363 & $4.56 *$ & 0.033 & $1.42(\mathrm{~T})$ & 100 & 9.50 & 0.002 & $5.30(\mathrm{~T})$ \\
\hline & FSIQ & 363 & 4.55 & 0.033 & $2.74(\mathrm{~T})$ & 100 & 7.14 & 0.008 & $5.35(\mathrm{~T})$ \\
\hline
\end{tabular}

*Stratification significant at $P=0.05$

Note: $\mathrm{N}$ denotes the number of individuals informative for the within family association test, i.e. those individuals that occur in families with more than one genotype. QTDT assumes equal genotypes for MZ twins and includes non-typed MZ co-twins with IQ scores. Abbreviation: GE genotypic effect (increaser allele).

regions of most importance to intelligence within introns 4 and 5. These regions are poorly conserved regions among relatively distant species, although they are conserved among primate species. Interestingly, the variant associated in the young cohort (rs324650) is located within a SINE repeat (MIRb). SINE repeats belongs to a wide family of transposable elements, which constitute the largest class of interspersed repeats that are found in our genome $(12 \%)$ together with long interspersed repeats (LINE) an long terminal repeats (LTRs) [43]. SINE repeats transpose through a RNA intermediate (reverse transcription process). All eukaryotic genomes contain mobile elements (retrosposable elements), although the proportion and activity of the classes of elements varies widely between genomes [44]. The CHRM2 gene, like its G-protein receptor counterparts, shares the interestingly feature - at least form a functional perspective - of being an intronless protein [45], which is also observed among dopamine receptors [46], widely studied in relation to attention deficits.

Recent research has revealed a potential functionality of retroposons in a gene-regulatory context [38,47-50]. It has been postulated that retroposon insertion processes may favour the generation of intronless proteins (for a review see Flavell 1995 and Brosius 2003 [51,52]). If this hypothesis holds, the resulting intronless proteins are expected to contain exons among their 5'UTR region. Not surprisingly, among G-proteins with intronless open reading frames (ORFs), about $18 \%$ have been reported to contain untranslated exons on their 5'UTR $[46,53]$.

The majority of mammalian GPCRs are related to central nervous system activity, which often requires high and differential expression of many genes [53,54].

\section{Conclusion}

Multiple promoters and transcripts have been reported for the CHRM2 gene suggesting that the associated regions we identified harbour functional elements involved in regulation of transcription and/or alternative splicing [17-19]. Further investigation involving functional assays and non-coding polymorphisms may aid the search and subsequent identification of regulatory variants underlying normal cognitive variation. 
Table 5: Population and family-based QTDT results for adult cohort for the most significant variants among CHRM2 gene

\begin{tabular}{|c|c|c|c|c|c|c|c|c|c|}
\hline \multirow[b]{2}{*}{ Position (bp) } & \multirow[b]{2}{*}{ Phenotype } & \multicolumn{3}{|c|}{ Population-based } & \multicolumn{5}{|c|}{ Family-based } \\
\hline & & $\mathbf{N}_{\text {POPULATION }}$ & $\chi^{2}$ & $\mathbf{P}$ & GE & $\mathbf{N}_{\text {FAMILY }}$ & $\chi^{2}$ & $\mathbf{P}$ & GE \\
\hline rs2350780 & $\mathrm{PIQ}$ & 359 & 0.26 & 0.610 & $0.47(\mathrm{~A})$ & 95 & 3.62 & 0.057 & $3.31(\mathrm{~A})$ \\
\hline \multirow[t]{2}{*}{ (136243509) } & VIQ & 359 & 0.01 & 0.920 & $0.12(\mathrm{~A})$ & 95 & 0.62 & 0.431 & $1.26(\mathrm{~A})$ \\
\hline & FSIQ & 359 & 0.05 & 0.823 & $0.22(\mathrm{~A})$ & 95 & 1.98 & 0.159 & $2.22(\mathrm{~A})$ \\
\hline rsI364409 & PIQ & 350 & 0.15 & 0.699 & $0.35(\mathrm{~A})$ & 92 & 4.90 & 0.027 & $3.13(\mathrm{~A})$ \\
\hline \multirow[t]{2}{*}{ (136262573) } & VIQ & 350 & 0.05 & 0.823 & $0.24(\mathrm{~A})$ & 92 & 0.02 & 0.888 & $1.05(\mathrm{~A})$ \\
\hline & FSIQ & 350 & 0.05 & 0.823 & $0.22(\mathrm{~A})$ & 92 & 1.25 & 0.264 & $0.72(\mathrm{~A})$ \\
\hline rs7782965 & PIQ & 345 & 0.94 & 0.332 & $0.93(C)$ & 91 & 5.29 & 0.021 & $3.36(\mathrm{C})$ \\
\hline \multirow[t]{2}{*}{$(136274673)$} & VIQ & 345 & 0.24 & 0.624 & $0.49(\mathrm{C})$ & 91 & 0.33 & 0.566 & $0.16(\mathrm{C})$ \\
\hline & FSIQ & 345 & 0.43 & 0.512 & $0.67(\mathrm{C})$ & 91 & 2.08 & 0.149 & $1.60(\mathrm{C})$ \\
\hline rsI378646 & PIQ & 363 & I.08* & 0.303 & $1.05(\mathrm{~A})$ & 90 & 6.48 & 0.011 & 3.77 (A) \\
\hline \multirow[t]{2}{*}{$(|362| 4872)$} & VIQ & 363 & 0.61 & 0.435 & $0.73(\mathrm{~A})$ & 90 & 1.27 & 0.26 & $1.10(\mathrm{~A})$ \\
\hline & FSIQ & 363 & 0.76 & 0.383 & $0.78(\mathrm{~A})$ & 90 & 3.65 & 0.056 & $2.36(\mathrm{~A})$ \\
\hline rs206II74 & PIQ & 389 & $4.64^{*}$ & 0.031 & $2.10(A)$ & 101 & 9.14 & 0.003 & 6.89 (A) \\
\hline \multirow[t]{2}{*}{$(136311940)$} & VIQ & 389 & 0.06 & 0.806 & $0.24(\mathrm{~A})$ & 101 & 0.01 & 0.920 & $1.78(\mathrm{~A})$ \\
\hline & FSIQ & 389 & 0.97 & 0.325 & $0.89(\mathrm{~A})$ & 101 & 1.82 & 0.177 & $3.76(\mathrm{~A})$ \\
\hline rsI74II56I & PIQ & 306 & 0.15 & 0.699 & $0.47(\mathrm{~T})$ & 79 & 1.28 & 0.589 & $0.69(\mathrm{C})$ \\
\hline \multirow[t]{2}{*}{$(136332728)$} & VIQ & 306 & 0.42 & 0.517 & $0.24(\mathrm{~T})$ & 79 & 0.15 & 0.699 & $0.44(\mathrm{~T})$ \\
\hline & FSIQ & 306 & 0.02 & 0.888 & $0.11(T)$ & 79 & 0.60 & 0.439 & $0.08(\mathrm{C})$ \\
\hline rs324640 & PIQ & 386 & 2.37 & 0.124 & $1.40(\mathrm{~A})$ & 123 & 2.36 & 0.126 & $3.05(\mathrm{~A})$ \\
\hline \multirow[t]{2}{*}{$(136339536)$} & VIQ & 386 & 0.02 & 0.888 & $0.12(\mathrm{~A})$ & 123 & 0.21 & 0.647 & $1.57(\mathrm{~A})$ \\
\hline & FSIQ & 386 & 0.54 & 0.462 & $0.67(\mathrm{~A})$ & 123 & 1.04 & 0.308 & $2.22(\mathrm{~A})$ \\
\hline rs324650 & PIQ & 369 & 2.09 & 0.148 & $1.28(\mathrm{~A})$ & 117 & 2.69 & 0.101 & $1.69(\mathrm{~T})$ \\
\hline \multirow[t]{2}{*}{$(136344201)$} & VIQ & 369 & 0.15 & 0.699 & $0.36(\mathrm{~A})$ & 117 & 0.00 & 1.000 & $0.78(\mathrm{~T})$ \\
\hline & FSIQ & 369 & 0.13 & 0.718 & $0.33(\mathrm{~T})$ & 117 & 0.58 & 0.446 & $0.77(\mathrm{~T})$ \\
\hline
\end{tabular}

*Stratification significant at $P=0.05$

Note: $\mathrm{N}$ denotes the number of individuals informative for the within family association test, i.e. those individuals that occur in families with more than one genotype. QTDT assumes equal genotypes for MZ twins and includes non-typed MZ co-twins with IQ scores. Abbreviation: GE genotypic effect (increaser allele).

\section{Competing interests}

The author(s) declare that they have no competing interests.

\section{Authors' contributions}

MFG conducted the SNP selection and genotyping. MFG and DP performed the statistical analyses. DNA was provided by DIB. Phenotypic data was provided by DIB, EJC, TJC and DP. MFG drafted the manuscript under DP and $\mathrm{PH}$ supervision. DP and $\mathrm{PH}$ supervised the study. All authors read and approved the final manuscript.

\section{Acknowledgements}

Supported by the Universitair Stimulerings Fonds (grant number 96/22), the Human Frontiers of Science Program (grant number rg0154/1998-B), the Netherlands Organization for Scientific Research (NWO) grants 904-57-94 and NWO/SPI 56-464-14192. DP is supported by GenomEUtwin grant (EU/QLRT-200I-01254) and by NWO/MaGW Vernieuwingsimpuls 016065-3 I8. This study was supported by the Centre for Medical Systems Biology (CMSB), a centre of excellence approved by the Netherlands Genomics Initiative/Netherlands Organization for Scientific Research (NWO). We thank all the twin families participating in this study as well as the Dutch Brain Bank for samples, Saskia van Mil and David Sondervan for technical support and Dina Ruano for valuable comments.

\section{References}

I. Cherny SS, Cardon LR: General cognitive ability. In Nature and nurture during middle childhood Edited by: de Fries J, Plomin R, Fulker D Oxford, Blackwell Publishers; 1994:46-56.

2. Plomin R, Turic DM, Hill L, Turic DE, Stephens M, Williams J, Owen MJ, O'Donovan MC: A functional polymorphism in the succinate-semialdehyde dehydrogenase (aldehyde dehydrogenase 5 family, member AI) gene is associated with cognitive ability. Mol Psychiatry 2004, 9(6):582-586.

3. Buyske S, Bates ME, Gharani N, Matise TC, Tischfield JA, Manowitz P: Cognitive traits link to human chromosomal regions. Behav Genet 2006, 36(I):65-76.

4. Posthuma D, Luciano M, Geus EJ, Wright MJ, Slagboom PE, Montgomery GW, Boomsma DI, Martin NG: A Genomewide Scan for Intelligence Identifies Quantitative Trait Loci on $2 q$ and $6 p$. Am J Hum Genet 2005, 77(2):318-326.

5. Dick DM, Aliev F, Bierut L, Goate A, Rice J, Hinrichs A, Bertelsen S, Wang JC, Dunn G, Kuperman S, Schuckit M, Nurnberger J Jr., Porjesz B, Beglieter H, Kramer J, Hesselbrock V: Linkage Analyses of IQ in the Collaborative Study on the Genetics of Alcoholism (COGA) Sample. Behav Genet 2006, 36(I):77-86.

6. Polderman TJC, Gosso MF, Posthuma D, Van Beijsterveldt TC, Heutink P, Verhulst FC, Boomsma DI: A longitudinal twin study on IQ, executive functioning, and attention problems during childhood and early adolescence. Acta Neurol Belg 2006, 106(4): $|9|-207$.

7. Comings DE, Wu S, Rostamkhani M, McGue M, Lacono WG, Cheng LS, MacMurray JP: Role of the cholinergic muscarinic 2 receptor (CHRM2) gene in cognition. Mol Psychiatry 2003, 8(I): | 0 - II.

8. Gosso MF, van Belzen MJ, de Geus EJC, Polderman JC, Heutink P, Boomsma DI, Posthuma D: Association between the CHRM2 gene and intelligence in a sample of 304 Dutch families. In 
Genes, Brain and Behavior Volume 5. Blackwell Publishing: 2006:577-584

9. Dick DM, Aliev F, Kramer J, Wang JC, Hinrichs A, Bertelsen S, Kuperman S, Schuckit M, Nurnberger J Jr., Edenberg H], Porjesz B, Begleiter H, Hesselbrock V, Goate A, Bierut L: Association of CHRM2 with IQ: Converging Evidence for a Gene Influencing Intelligence. Behav Genet 2007, 37(2):265-272.

10. Levey Al, Kitt CA, Simonds WF, Price DL, Brann MR: Identification and localization of muscarinic acetylcholine receptor proteins in brain with subtype-specific antibodies. J Neurosci |99|, I I(10):3218-3226.

II. Volpicelli LA, Levey Al: Muscarinic acetylcholine receptor subtypes in cerebral cortex and hippocampus. Prog Brain Res 2004, 145:59-66.

12. Orsetti M, Casamenti F, Pepeu G: Enhanced acetylcholine release in the hippocampus and cortex during acquisition of an operant behavior. Brain Res 1996, 724(I):89-96.

13. Carey G], Billard W, Binch H 3rd, Cohen-Williams M, Crosby G, Grzelak M, Guzik H, Kozlowski JA, Lowe DB, Pond AJ, Tedesco RP, Watkins RW, Coffin VL: SCH 57790, a selective muscarinic $M(2)$ receptor antagonist, releases acetylcholine and produces cognitive enhancement in laboratory animals. Eur $J$ Pharmacol 200I, 43I(2): I89-200.

14. Accili D, Fishburn CS, Drago J, Steiner H, Lachowicz JE, Park BH, Gauda EB, Lee EJ, Cool MH, Sibley DR, Gerfen CR, Westphal H, Fuchs S: A targeted mutation of the D3 dopamine receptor gene is associated with hyperactivity in mice. Proc Natl Acad Sci US A 1996, 93(5): 1945-1949.

15. Seeger T, Fedorova I, Zheng F, Miyakawa T, Koustova E, Gomeza J, Basile AS, Alzheimer C, Wess J: M2 muscarinic acetylcholine receptor knock-out mice show deficits in behavioral flexibility, working memory, and hippocampal plasticity. J Neurosci 2004, 24(45): $10117-10127$.

16. Gautam D, Duttaroy A, Cui Y, Han S, Deng C, Seeger T, Alzheimer C, Wess J: MI-M3 muscarinic acetylcholine receptor-deficient mice: novel phenotypes. J Mol Neur 2006, 30:157-160.

17. Fenech AG, Billington CK, Swan C, Richards S, Hunter T, Ebejer MJ, Felice AE, Ellul-Micallef R, Hall IP: Novel polymorphisms influencing transcription of the human CHRM2 gene in airway smooth muscle. Am J Respir Cell Mol Biol 2004, 30(5):678-686.

18. Krejci A, Bruce AW, Dolezal V, Tucek S, Buckley NJ: Multiple promoters drive tissue-specific expression of the human $M$ muscarinic acetylcholine receptor gene. J Neurochem 2004 $91(1): 88-98$

19. Zhou C, Fryer AD, Jacoby DB: Structure of the human M(2) muscarinic acetylcholine receptor gene and its promoter. Gene 200I, 27I(I):87-92.

20. Abecasis GR, Cardon LR, Cookson WO: A general test of association for quantitative traits in nuclear families. Am J Hum Genet 2000, 66(I):279-292.

21. Fulker DW, Cherny SS, Sham PC, Hewitt JK: Combined linkage and association sib-pair analysis for quantitative traits. $\mathrm{Am} \mathrm{J}$ Hum Genet 1999, 64(I):259-267.

22. Posthuma D, de Geus EJ, Boomsma DI, Neale MC: Combined linkage and association tests in $\mathbf{m x}$. Behav Genet 2004 34(2): $179-196$.

23. Boomsma DI, de Geus EJ, Vink JM, Stubbe JH, Distel MA, Hottenga JJ, Posthuma D, van Beijsterveldt TC, Hudziak J], Bartels M, Willemsen G: Netherlands Twin Register: from twins to twin families. Twin Res Hum Genet 2006, 9(6):849-857.

24. Bartels M, Rietveld MJ, Van Baal GC, Boomsma DI: Genetic and environmental influences on the development of intelligence. Behav Genet 2002, 32(4):237-249.

25. Posthuma D, de Geus EJ, Boomsma DI: Perceptual speed and IQ are associated through common genetic factors. Behav Genet 200I, 3 I (6):593-602.

26. Polderman TJC Stins JF, Posthuma D, Gosso MF, Verhulst FC Boomsma DI: The phenotypic and genotypic relation between working memory speed and capacity. Intelligence 2006 34:549-560.

27. Gosso MF, van Belzen M, de Geus EJ, Polderman JC, Heutink P, Boomsma DI, Posthuma D: Association between the CHRM2 gene and intelligence in a sample of 304 Dutch families. Genes Brain Behav 2006, 5(8):577-584.

28. Hoekstra C, Meijer P, Kluft C, Heutink P, Smit G, de Geus E, Smit JH, van Bruggen A, Montgomery GW, Boomsma DI: Genetics of dizy- gotic twinning: a feasibility study for a biobank. Twin Res 2004 , 7(6):556-563

29. Wechsler D: Wechsler Intelligence Scale for Children-Revised (WISC-R). Lisse , Swets \& Zeitlinger; 1986.

30. Wechsler D: WAIS-III Wechsler Adult Intelligence Scale . San Antonio, Texas , Psychological Corporation; 1997.

3I. Meulenbelt I, Droog S, Trommelen G], Boomsma DI, Slagboom PE: High-yield noninvasive human genomic DNA isolation method for genetic studies in geographically dispersed families and populations. Am J Hum Genet 1995, 57(5): | 252-1254.

32. Min JL, Lakenberg N, Bakker-Verweij M, Suchiman E, Boomsma DI, Slagboom PE, Meulenbelt I: High microsatellite and SNP genotyping success rates established in a large number of genomic DNA samples extracted from mouth swabs and genotypes. Twin Res Hum Genet 2006, 9:50I-506.

33. Miller SA, Dykes DD, Polesky HF: A simple salting out procedure for extracting DNA from human nucleated cells. Nucleic Acids Res 1988, 16(3): 1215.

34. Nederland Brain Bank [http://www.brainbank.nl]

35. Centre d'Etude du polymorphisme Humain [http://www.hap map.org/thehapmap.html.en]

36. Haploview [http://www.broad.mit.edu/mpg/haploview/]

37. Gabriel SB, Schaffner SF, Nguyen H, Moore JM, Roy J, Blumenstiel B, Higgins J, DeFelice M, Lochner A, Faggart M, Liu-Cordero SN, Rotimi C, Adeyemo A, Cooper R, Ward R, Lander ES, Daly MJ, Altshuler D: The structure of haplotype blocks in the human genome. Science 2002, 296(5576):2225-2229.

38. Mei $L, Y a n$ JC: [Advances in subclassifications of muscarinic acetylcholine receptors]. Sheng Li Ke Xue Jin Zhan 1985, 16(3):248-252.

39. Niculescu MD, Craciunescu CN, Zeisel SH: Dietary choline deficiency alters global and gene-specific DNA methylation in the developing hippocampus of mouse fetal brains. Faseb J 2006, 20(I):43-49.

40. Olivera S, Henley JM, Rodriguez-lthurralde D: AMPA receptor potentiation by acetylcholinesterase is age-dependently upregulated at synaptogenesis sites of the rat brain. Int J Dev Neurosci 2003, 2 I (I):49-6I.

4I. Toga AW, Thompson PM, Sowell ER: Mapping brain maturation. Trends Neurosci 2006, 29(3): 148-159.

42. Lein ES, Hawrylycz MJ, Ao N, Ayres M, Bensinger A, Bernard A, Boe AF, Boguski MS, Brockway KS, Byrnes EJ, Chen L, Chen L, Chen TM, Chi Chin M, Chong J, Crook BE, Czaplinska A, Dang CN, Datta S, Dee NR, Desaki AL, Desta T, Diep E, Dolbeare TA, Donelan MJ, Dong HW, Dougherty JG, Duncan BJ, Ebbert AJ, Eichele G, Estin LK, Faber C, Facer BA, Fields R, Fischer SR, Fliss TP, Frensley C, Gates SN, Glattfelder KJ, Halverson KR, Hart MR, Hohmann JG, Howell MP, Jeung DP, Johnson RA, Karr PT, Kawal R, Kidney JM, Knapik RH, Kuan CL, Lake JH, Laramee AR, Larsen KD, Lau C, Lemon TA, Liang AJ, Liu Y, Luong LT, Michaels J, Morgan J], Morgan RJ, Mortrud MT, Mosqueda NF, Ng LL, Ng R, Orta G], Overly CC, Pak TH, Parry SE, Pathak SD, Pearson OC, Puchalski RB, Riley ZL, Rockett HR, Rowland SA, Royall IJ, Ruiz MJ, Sarno NR, Schaffnit K, Shapovalova NV, Sivisay T, Slaughterbeck CR, Smith SC, Smith KA, Smith BI, Sodt AJ, Stewart NN, Stumpf KR, Sunkin SM, Sutram M, Tam A, Teemer CD, Thaller C. Thompson CL, Varnam LR, Visel A, Whitlock RM, Wohnoutka PE, Wolkey CK, Wong VY, Wood M, Yaylaoglu MB, Young RC, Youngstrom BL, Feng Yuan X, Zhang B, Zwingman TA, Jones AR: Genomewide atlas of gene expression in the adult mouse brain. Nature 2007, 445(7 I 24): 168.

43. Smit AF: Interspersed repeats and other mementos of transposable elements in mammalian genomes. Curr Opin Genet Dev 1999, 9(6):657-663.

44. Kidwell MG, Lisch DR: Transposable elements and host genome evolution. Trends In Ecology And Evolution 2000, I5(3):95-99.

45. Fredriksson R, Lagerstrom MC, Lundin LG, Schioth HB: The G-Protein-Coupled Receptors in the Human Genome Form Five Main Families. Phylogenetic Analysis, Paralogon Groups, and Fingerprints. Mol Pharmacol 2003, 63(6): $1256-1272$.

46. O'Dowd BF: Structures of dopamine receptors. J Neurochem 1993, 60(3):804-816.

47. Bejerano G, Lowe CB, Ahituv N, King B, Siepel A, Salama SR, Rubin $E M$, Kent WJ, Haussler D: A distal enhancer and an ultraconserved exon are derived from a novel retroposon. Nature 2006, 44 I (7089):87-90. 
48. Han JS, Boeke JD: LINE-I retrotransposons: modulators of quantity and quality of mammalian gene expression? Bioessays 2005, 27(8):775-784.

49. Hellmann-Blumberg U, Hintz MF, Gatewood JM, Schmid CW: Developmental differences in methylation of human Alu repeats. Mol Cell Biol 1993, 13(8):4523-4530.

50. Muratani K, Hada T, Yamamoto Y, Kaneko T, Shigeto Y, Ohue T, Furuyama J, Higashino K: Inactivation of the cholinesterase gene by Alu insertion: possible mechanism for human gene transposition. Proc Natl Acad Sci U S A 1991, 88(24): I I315-II319.

5I. Flavell AJ: Retroelements, reverse transcriptase and evolution. Comp Biochem Physiol B Biochem Mol Biol 1995, I I O(I):3-I5.

52. Brosius J: The contribution of RNAs and retroposition to evolutionary novelties. Genetica 2003, I I 8(2-3):99-II6.

53. Rouquier S, Taviaux S, Trask BJ, Brand-Arpon V, van den Engh G, Demaille J, Giorgi D: Distribution of olfactory receptor genes in the human genome. Nat Genet 1998, I8(3):243-250.

54. Lee CJ, Irizarry K: Alternative splicing in the nervous system: an emerging source of diversity and regulation. Biological Psychiatry 2003, 54(8):77I.

\section{Pre-publication history}

The pre-publication history for this paper can be accessed here:

http://www.biomedcentral.com/1471-2350/8/66/prepub

Publish with Biomed Central and every scientist can read your work free of charge

"BioMed Central will be the most significant development for disseminating the results of biomedical research in our lifetime. "

Sir Paul Nurse, Cancer Research UK

Your research papers will be:

- available free of charge to the entire biomedical community

- peer reviewed and published immediately upon acceptance

- cited in PubMed and archived on PubMed Central

- yours - you keep the copyright

Submit your manuscript here:

http://www.biomedcentral.com/info/publishing_adv.asp
BioMedcentral 